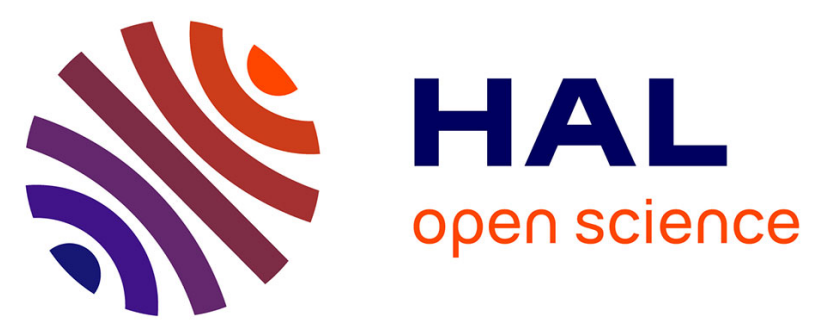

\title{
Operando DRIFT Spectroscopy Characterization of Intermediate Species on Catalysts Surface in VOC Removal from Air by Non-thermal Plasma Assisted Catalysis
}

\author{
Anthony Rodrigues, Jean-Michel Tatibouët, Elodie Fourre
}

\section{To cite this version:}

Anthony Rodrigues, Jean-Michel Tatibouët, Elodie Fourre. Operando DRIFT Spectroscopy Characterization of Intermediate Species on Catalysts Surface in VOC Removal from Air by Non-thermal Plasma Assisted Catalysis. Plasma Chemistry and Plasma Processing, 2016, 36 (4), pp.901-915. 10.1007/s11090-016-9718-1 . hal-03374656

\author{
HAL Id: hal-03374656 \\ https://hal.science/hal-03374656
}

Submitted on 12 Oct 2021

HAL is a multi-disciplinary open access archive for the deposit and dissemination of scientific research documents, whether they are published or not. The documents may come from teaching and research institutions in France or abroad, or from public or private research centers.
L'archive ouverte pluridisciplinaire HAL, est destinée au dépôt et à la diffusion de documents scientifiques de niveau recherche, publiés ou non, émanant des établissements d'enseignement et de recherche français ou étrangers, des laboratoires publics ou privés. 


\title{
Operando DRIFT spectroscopy characterization of intermediate species on catalysts surface in VOC removal from air by non-thermal plasma assisted catalysis.
}

\author{
Anthony RODRIGUES, Jean-Michel TATIBOUËT, Elodie FOURRE \\ Institut de Chimie des Milieux et Matériaux de Poitiers (IC2MP), UMR CNRS 7285 \\ Université de Poitiers, Ecole Nationale Supérieure d'Ingénieurs de Poitiers (ENSIP) \\ 1, rue marcel Doré, TSA 41105, 86073 Poitiers cedex 9 (France)
}

\begin{abstract}
An innovative plasma discharge reactor was developed to fit an infrared cell and to allow the in situ characterization of isopropanol (IPA) and toluene decomposition at the surface of three metal oxides $\left(\gamma-\mathrm{Al}_{2} \mathrm{O}_{3}, \mathrm{TiO}_{2}\right.$ and $\left.\mathrm{CeO}_{2}\right)$. The impact of the plasma discharge on the conversion of these pollutants, with the material placed in the discharge area, was studied under real time conditions at atmospheric pressure via infrared analysis. The plasma treatment of IPA molecules led to the formation of acetone, propene, acetic acid and/or formic acid. By contrast, the toluene oxidation led to the rapid opening of the aromatic ring, followed by the total oxidation through carboxylic formation of the species arising from the toluene molecules fragmentation.
\end{abstract}

\section{Keywords}

In-situ characterization, infrared spectroscopy, non-thermal plasma, VOC

Corresponding author: Elodie FOURRE (elodie.fourre@univ-poitiers.fr) 


\section{Introduction}

Non thermal atmospheric plasma (NTAP) is now recognized as an innovative technology applied to a wide range of applications (etching, deposition of thin film, volatile organic compound oxidation, surface functionalization, biomedical...) [1]. The advantageous properties of NTAP, in terms of energetic and environmental aspects, are responsible for the enhanced research in this field. Non thermal atmospheric plasmas are produced by a variety of electrical discharges or electron beams leading to plasmas such as corona discharges, gliding arc discharges, dielectric barrier discharges (DBD), plasma needle, plasma jets and micro hollow cathode discharges [2]. Non thermal plasmas are generated by the application of a high potential difference between two electrodes that leads to a strong electrical field, resulting in the formation of a highly reactive environment favorable to various reactions. For decades, non-thermal atmospheric plasma was used mainly for the production of ozone and water purification [3]. More recently, due to a greater concern on environmental issues, research on waste gas treatment, volatile organic compounds (VOCs) removal has been largely studied. In particular, the presence of a catalyst in the plasma discharge resulted in a synergistic effect and improved VOCs conversion [4-6]. However, if research has shown tremendous results on VOCs conversion, a few points remain unclear. It concerns essentially the interactions between the chemical species generated in the plasma discharge and a material surface. The willingness to identify active species in the plasma discharge is very challenging. It is a complex field of research, as the species concentration, nature and energetic power are dependent of the plasma reactor configuration, chemical and electrical parameters. Already, research has been dedicated to in situ identification of plasma species in the gaseous phase by spectroscopic methods [7-15]. Most of these studies are dealing with the characterization of the plasma species but not with their reactivity. Rivallan et al. [11] have studied the evolution of air/ $/ \mathrm{CO}_{2}$ gas mixture under non-thermal plasma by in situ FTIR at the microsecond time-scale. They showed that the mechanism of $\mathrm{CO}_{2}$ consumption is reversible and that $\mathrm{CO}_{2}$ molecules are excited through a collision with excited $\mathrm{N}_{2}$ molecules, where the transfer of energy occurs by a resonant effect. Other authors tried to elucidate some aspects of the ion chemistry occurring in dielectric barrier and corona discharges with benzene/air [7] or different gases such as gas mixtures including $\mathrm{Ar}, \mathrm{H}_{2}, \mathrm{~N}_{2}, \mathrm{O}_{2}$ and $\mathrm{CH}_{4}$ as plasma precursors [8]. OH radical concentration was determined by indirect detection with salicylic acid [13] and 
direct measurement by laser-induced fluorescence [12]. Kim et al. [15] have reviewed recent progresses in understanding the interaction of NTP and catalysts. They insisted on the effects of the electrical characteristics of the catalyst on the plasma discharge generation and therefore chemical reactivity. In a recent publication [14], we have shown that the decomposition of isopropanol (IPA) by non-thermal plasma on $\gamma-\mathrm{Al}_{2} \mathrm{O}_{3}$, analyzed by operando Fourier Transform Infrared (FTIR) under low vacuum could proceed via oxidation, aldolization and fragmentation mechanisms. Such cascade reactions were only possible when $\gamma-\mathrm{Al}_{2} \mathrm{O}_{3}$ catalyst was placed in the discharge zone. This VOC has been studied and published in the literature with results essentially based on the analysis of the outlet gas composition. IPA conversion leads to the formation of acetone, acetic acid, formaldehyde (when the reaction is incomplete), formic acid, $\mathrm{CO}_{2}$ and $\mathrm{H}_{2} \mathrm{O}$ [14-19]. Christensen et al. [20] reported a spectroscopic study of non-thermal plasma in an air-fed dielectric barrier discharge plasma jet. In situ analysis of the plasma glow and downstream gas by FTIR revealed the presence of various species such as $\mathrm{O}_{3}, \mathrm{~N}_{2} \mathrm{O}_{5}, \mathrm{~N}_{2} \mathrm{O}, \mathrm{HNO}_{3}, \mathrm{CO}_{2}, \mathrm{CO}$ and a vibrationally excited form of $\mathrm{CO}_{2}$ (i.e. $\mathrm{CO}_{2}{ }_{2}$ (v)).

Here we are dealing with a non-thermal plasma reactor set at atmospheric pressure and coupled to reflectance infrared spectroscopy. The test reactions studied in this work concerned the removal of isopropanol and toluene from $\gamma-\mathrm{Al}_{2} \mathrm{O}_{3}, \mathrm{TiO}_{2}$ and $\mathrm{CeO}_{2}$ surfaces by non-thermal plasma. The impact of the plasma discharge on the conversion of these pollutants, with the material placed in the discharge area, was studied under real time conditions at atmospheric pressure via infrared analysis.

\section{Experimental}

A non-thermal plasma at atmospheric pressure (NTPAP) reactor was developed and optimized for its combination with a DRIFT spectrometer. The spectrometer was modified in order to carry out a DBD plasma in the DRIFT cell while a direct surface analysis was carried out. The cell was made of Polytetrafluoroethylene (PTFE) and included a cylindrical base $(30 \mathrm{~mm}$ diameter, $29 \mathrm{~mm}$ height) and a conical top (26 mm height). The cone was equipped with two ZnSe windows, to allow the passage of the IR beam, and one glass window (figure 1a) to view the discharge. The volumic dielectric barrier discharge plasma consisted in a tip electrode (figure $1 \mathrm{~b}$, tip diameter $0.5 \mathrm{~mm}$ ) held in the centre of the cone and a counter electrode (10 
$\mathrm{mm} \times 10 \mathrm{~mm}$ copper tape) placed under a dielectric $(0.5 \mathrm{~mm}$ thick in PEEK: polyether ether ketone). The sample was placed on the dielectric, underneath the tip. The gap between the tip and dielectric surface was kept constant $(1 \mathrm{~mm})$. The electrodes were connected, via a capacitor of known value $\left(C_{m}=0.56 \mathrm{nF}\right)$, to a high voltage power amplifier (Trek, 20/20A) coupled to a function generator (TTi TG1010A). Experiments were carried out in an airtight cell with the possibility to vary the chemical and electrical parameters. FTIR Spectrometer Frontier (PerkinElmer, UK), equipped with a Mercury Cadmium Telluride (MCT) detector, was used to record IR spectra in the $4000-900 \mathrm{~cm}^{-1}$ range with a resolution of $8 \mathrm{~cm}^{-1}$. Each spectrum is the accumulation of 50 analyses allowing an acquisition time below $1 \mathrm{~min}$. The contributions of gaseous $\mathrm{H}_{2} \mathrm{O}$ and $\mathrm{CO}_{2}$ were subtracted when scanning. Before each experiment the cell was purged with dry air for $10 \mathrm{~min}\left(30 \mathrm{~mL} \cdot \mathrm{min}^{-1}\right)$ before the initiation of the plasma discharge. IR spectra of the sample wafer were then recorded in reflection mode (DRIFT: Diffuse Reflectance Infrared Fourier Transform) as a function of the duration of DBD plasma. Scans were taken while the plasma treatment was switched on and over a period of time going from $1 \mathrm{~min}$ to 8 hours. All the experiments were carried out at atmospheric pressure.

The DBD experiments were studied under "dynamic" conditions, a flow rate of $30 \mathrm{~mL}$. $\mathrm{min}^{-1}$ of gas (dry air, Air liquide) was constantly running in the cell chamber.

The power injected in the reactor was determined by the analysis of the Lissajous figure (figure 2 ) that reports the transferred electrical charge $Q_{m}$ as a function of the applied voltage $\left(U_{a}\right)$ using the so-called "Manley method" [21]. $Q_{m}$ was calculated from the measured voltage $\left(U_{m}\right)$ across the capacitor $\left(C_{m}\right)$ connected in series to the ground electrode. The energy injected, $E$ (per cycle) was calculated from the integration of the area formed by the Lissajous figure. The energy allowed the calculation of the power (in W) injected in the reactor as well as the specific energy $E_{\text {spe }}$ (in J. $\mathrm{L}^{-1}$ ) following equation 1 and 2 , where $\mathrm{f}$ is the frequency (in $\mathrm{Hz}$ ) and $\mathrm{D}$ the gas flow rate in $\left(L . S^{-1}\right)$ :

$$
\begin{aligned}
& P=E \times f \\
& E_{\text {spe }}=\frac{P}{D}
\end{aligned}
$$


The experiments were carried out at $16 \mathrm{kV}(500 \mathrm{~Hz})$, where the plasma discharge was stable, homogeneous and sufficiently energetic to promote excited species. These parameters correspond to a power of $24 \mathrm{~mW}$ and an energy density of $48 \mathrm{~J} \cdot \mathrm{L}^{-1}$.

The catalyst sample was in the form of a thin layer of powder (50-100 mg) slightly pressed on the dielectric plate in order to avoid its spraying under the effect of gas flow rate and plasma. The three oxides were commercial oxides (table 1). The specific surface area of the samples was determined by the BET (Brunauer-Emmett-Teller) method from the nitrogen adsorption isotherms at $-196{ }^{\circ} \mathrm{C}$ in an automated Micromeritics Tristar 3000 apparatus after drying for 8 hours at $400{ }^{\circ} \mathrm{C}$.

\section{Results}

Electrical parameters of the plasma generated in the IR cell were determined with and without the presence of a catalytic material. The influence of the material on the plasma discharge was evaluated by comparing the variation of the plasma power as a function of applied voltage (Figure 3). A slight decrease of the power is noticed when $\mathrm{Al}_{2} \mathrm{O}_{3}$ is placed in the discharge, likely due to the slight modification of the dielectric properties of the dielectric plate when covered by alumina.

\subsection{Isopropanol removal}

All the surfaces were first placed in contact with a gas mixture air/IPA (100 ppm) at atmospheric pressure for 15 minutes. This was followed by a 10 min flow of air prior to the plasma treatment, also under air flow. Figure $4 \mathrm{~A}$ displays the evolution of the IR spectra of $\mathrm{Al}_{2} \mathrm{O}_{3}$ as a function of treatment time, from 1 to 60 minutes. The same experiment was carried out on the two other oxide surfaces of $\mathrm{CeO}_{2}$ and $\mathrm{TiO}_{2}$ (figures $5 \mathrm{~A}$ and $6 \mathrm{~A}$ ). Additionally, spectra of three likely products (acetic acid, formic acid and acetone) were recorded and are displayed in figures $4 \mathrm{~B}, 5 \mathrm{~B}$ and $6 \mathrm{~B}$. The spectra were recorded after 10 mins adsorption of a mixture of air/ product (100ppm) at atmospheric pressure followed by a 10 mins purge under air flow. The IR spectra were obtained after subtraction of the background spectrum of the sample under air before adsorption. For the three samples, after IPA adsorption and before plasma treatment, the predominant bands corresponding to the $\mathrm{C}-\mathrm{H}$ asymmetric and symmetric stretching ( $v$-as and $v$-s) were detected between 3030 and $2840 \mathrm{~cm}^{-1}$ and between 1510 and 
$1300 \mathrm{~cm}^{-1}$ for the methyl C-H asymmetric and symmetric bends ( $\delta$-as and $\delta$-s). Between 1255 and $1205 \mathrm{~cm}^{-1}, \delta-\mathrm{O}-\mathrm{H}$ from un-dissociated IPA was identified. Other components, with lower intensity, around 1150 and $1075 \mathrm{~cm}^{-1}$ were related to the $\mathrm{C}-\mathrm{O}$ stretch and $\mathrm{C}-\mathrm{C}$ skeletal of isopropoxide species, formed via dissociative adsorption of the IPA molecule or/and to molecularly adsorbed IPA [16, 22-25]. The negative bands in the $3750-3600 \mathrm{~cm}^{-1}$ region, corresponding to the surface hydroxyl groups of metallic oxides show that IPA adsorption can occur either as isopropoxy group (scheme 1- a) or by coordination with surface $\mathrm{OH}$ groups (scheme 1-b).

The remaining negative band even after oxidation of IPA by non-thermal plasma strongly suggests that the IPA is mostly adsorbed as an isopropoxy species (scheme 1-b) rather than by coordination with surface $\mathrm{OH}$ groups [26-28]. As soon as the discharge was initiated, the bands corresponding to the methyl group stretching (2975-2840 $\mathrm{cm}^{-1}$ region) decreased as a function of the plasma treatment time, whatever the sample. After 60 minutes of plasma treatment, a residual $\mathrm{C}-\mathrm{H}$ contribution is still visible which results from the formation of decomposition compounds such as acetone, aldehydes and/or acids. A very broad band going from 3340 to $2250 \mathrm{~cm}^{-1}$ emerged after 5 minutes of treatment for $\mathrm{TiO}_{2}$ and $\mathrm{CeO}_{2}$ and 20 minutes for $\gamma-\mathrm{Al}_{2} \mathrm{O}_{3}$ which corresponds to the $\mathrm{O}-\mathrm{H}$ stretch of carboxylic acid. This band is prominent on $\gamma-\mathrm{Al}_{2} \mathrm{O}_{3}$ and similarly, but less evident, on $\mathrm{TiO}_{2}$ and $\mathrm{CeO}_{2}$.

In the lower wavenumber region, the analysis is more difficult due to the overlapping of the bands. However, the progressive formation (from 1 to $60 \mathrm{~min}$ treatment) of a band corresponding to a $\mathrm{C}=\mathrm{O}$ group (ketone, aldehyde and/or carboxylic acid) and centered at 1730 , 1760 and $1712 \mathrm{~cm}^{-1}$ for $\gamma-\mathrm{Al}_{2} \mathrm{O}_{3}, \mathrm{TiO}_{2}$ and $\mathrm{CeO}_{2}$, respectively, is clearly identified. Regarding $\gamma-$ $\mathrm{Al}_{2} \mathrm{O}_{3}$ and $\mathrm{TiO}_{2}$, a shoulder within the ketone region band is visible at a lower wavenumber (1695 and $1730 \mathrm{~cm}^{-1}$ ) and correlates closely to the $\mathrm{C}=\mathrm{O}$ band of acetic and/or formic acids. $\mathrm{CeO}_{2}$ presents a much wider band, centered at $1712 \mathrm{~cm}^{-1}$, encompassing the $\mathrm{C}=\mathrm{O}$ contribution of the acids.

Bands of methyl bending vibrations $(\delta)$ evolved differently. On $\gamma-\mathrm{Al}_{2} \mathrm{O}_{3}$ surface, an increase and a broadening of the $\delta$-as C-H band $\left(1465 \mathrm{~cm}^{-1}\right)$, a decrease/shift of $\delta$-s C-H band (IPA: 1382 $\mathrm{cm}^{-1}$ ) to $1360 \mathrm{~cm}^{-1}$ were observed as a function of the treatment time. The band at $1360 \mathrm{~cm}^{-}$ 1, emerging after 5 minutes, is related to the methyl bending vibrations of acetone [29-31]. The bands at 1595 and $1465 \mathrm{~cm}^{-1}$ could be assigned to the $\mathrm{C}=\mathrm{C}$ stretching and $\mathrm{C}-\mathrm{H}$ bending 
mode of methyl or methylene group of propene, respectively [32], according to the products formation observed by IPA oxidation at low temperature on pure $\gamma-\mathrm{Al}_{2} \mathrm{O}_{3}$ [33]. Simultaneously, a small shoulder at $1225 \mathrm{~cm}^{-1}$ also appeared after 20 minutes treatment and the large band at $1730 \mathrm{~cm}^{-1}$ was assigned to acetone formation. The small residual contribution remaining at $1150 \mathrm{~cm}^{-1}$ could correspond to $\mathrm{C}-\mathrm{O}$ bonds stretching and assign to formic acid formation. These observations show that isopropoxide species formed by the dissociative adsorption of isopropanol give rise to acetone and formic acid on $\gamma-\mathrm{Al}_{2} \mathrm{O}_{3}$ when treated by non-thermal plasma under air.

On $\mathrm{TiO}_{2}$, an increase and a broadening of the $\delta$-as $\mathrm{C}-\mathrm{H}$ band $\left(1470 \mathrm{~cm}^{-1}\right)$ and the total disappearance of $\delta$-s $\mathrm{C}-\mathrm{H}$ band $\left(1385 \mathrm{~cm}^{-1}\right)$, were observed as a function of the plasma treatment time. The IPA bands at lower wavenumbers: $\delta-\mathrm{O}-\mathrm{H}\left(1253 \mathrm{~cm}^{-1}\right), \mathrm{C}-\mathrm{O}$ stretching and C-C skeletal elongation (1150 and $1075 \mathrm{~cm}^{-1}$ ), progressively weakened till complete disappearance as the plasma treatment time increased showing that IPA on $\mathrm{TiO}_{2}$ is rapidly oxidized into acetone followed by further decomposition into $\mathrm{CO}_{2}$ and gas phase water. $\mathrm{A}$ small acidic residue is visible from the broad band in the $3000 \mathrm{~cm}^{-1}$ region. Additionally, at $1470 \mathrm{~cm}^{-1}$ and in smaller extend at $1590 \mathrm{~cm}^{-1}$ bands were identified and corresponded to the $\mathrm{C}-\mathrm{H}$ bending and the $\mathrm{COO}^{-}$stretching, respectively.

On $\mathrm{CeO}_{2}$, the bands corresponding to the $\delta$-as $\left(1470 \mathrm{~cm}^{-1}\right)$ and $\delta$-s $\left(1390 \mathrm{~cm}^{-1}\right)$ bending mode of methyl are evolving and broadening as a function of the plasma treatment time. In the same time, a large band is growing at $1275 \mathrm{~cm}^{-1}$ which corresponds to the $\mathrm{O}-\mathrm{H}$ bending vibration mode of carboxylic acids. As for the two other samples, it is difficult to differentiate the different acids and their contribution due to the overlapping of the bands in this region. Cerium oxide that shows particularly broad bands makes it difficult to observe the evolution of acetone formation/oxidation on this surface. Finally, an interesting feature, only visible on $\mathrm{CeO}_{2}$ is the adsorption/desorption of $\mathrm{CO}_{2}$ in the $2300-2400 \mathrm{~cm}^{-1}$ region $\left(2365\right.$ and $\left.2333 \mathrm{~cm}^{-1}\right)$, that may arise from the decomposition of IPA into $\mathrm{CO}_{2}$. However, we have to be careful with this interpretation since published work on $\mathrm{CO}_{2}$ adsorption on $\gamma-\mathrm{Al}_{2} \mathrm{O}_{3}$ [34] or tin oxide [35] revealed the presence of bands in the $1900-1200 \mathrm{~cm}^{-1}$ range relative to adsorbed $\mathrm{CO}_{2}$, which may, in this case, be hidden by other contributions at low wavenumbers.

According to these observations, the steps following IPA stabilization on the surface can follow these two pathways: either its oxidation into acetone, either a $\mathrm{C}-\mathrm{C}$ bond breakage of a methyl 
group. Oxidation reactions taken place here can either come from a radical attack, probably from $\mathrm{O}^{\bullet}$ or ${ }^{\bullet} \mathrm{OH}$, on the $-\mathrm{OH}$ group of IPA, either via redox reactions of the adsorbed isopropoxide species on the metal oxide surface acid sites. C-C bond breakage can be achieved by ${ }^{\circ} \mathrm{OH}$ radical attack and the resulting methyl radical can react with oxygenated species to form formaldehyde, then formic acid. The other radical fragment, $\mathrm{CH}_{3} \mathrm{CH}{ }^{\bullet} \mathrm{OH}$, can then be oxidized in acetaldehyde, then in acetic acid. On alumina, the formation of propene from IPA dehydration can also occurs, followed by its decomposition into $\mathrm{CO}_{2}$ and $\mathrm{H}_{2} \mathrm{O}$.

\subsection{Toluene removal}

The experiments regarding toluene elimination were performed in the same conditions as for IPA removal. Toluene was previously adsorbed on the catalysts (100 ppm in air for $10 \mathrm{~min}$, $30 \mathrm{~mL} . \mathrm{min}^{-1}$ ) followed by purging with dry air before the start of the plasma treatment. The recorded spectra as a function of time are presented in figure 7 ( $A$ to $C$ ). As expected, on the three oxides the main reference IR bands of adsorbed toluene are visible at around 3100-3000 $\mathrm{cm}^{-1}$ domain corresponding to the $\mathrm{C}-\mathrm{H}$ aromatic (3030 and $3080 \mathrm{~cm}^{-1}$ ) and at 2930 and 2880 $\mathrm{cm}^{-1}$ corresponding to the $\mathrm{C}-\mathrm{H}$ stretching of the methyl group and at 1495, 1460 and $1610 \mathrm{~cm}^{-}$ 1, corresponding to the $\mathrm{C}-\mathrm{C}$ stretching in the aromatic ring. The negative bands at 1705 (bending mode of hydrogen bonded surface hydroxyls) and $3695 \mathrm{~cm}^{-1}$ (stretching mode) could be assigned to the loss of surface hydroxyl group upon toluene adsorption [36-40]. On $\mathrm{CeO}_{2}$ and to a lesser extent on $\gamma-\mathrm{Al}_{2} \mathrm{O}_{3}$, a small contribution of in plane $\mathrm{C}-\mathrm{H}$ bending at 1081 and $1035 \mathrm{~cm}^{-1}$ was identified as well as weak bands at 1160 and $1180 \mathrm{~cm}^{-1}$ for $\mathrm{CeO}_{2}$ and $\gamma-\mathrm{Al}_{2} \mathrm{O}_{3}$, respectively. Finally, a weak overtone in the $2000-1800 \mathrm{~cm}^{-1}$ region is detected.

As soon as the plasma was generated, and this independently of the catalyst sample tested, the $\mathrm{C}-\mathrm{H}$ aromatic bands (3030 and $3080 \mathrm{~cm}^{-1}$ ) decreased rapidly after only one minute of plasma treatment and this until 10 minutes. At 10 minutes, no $\mathrm{C}-\mathrm{H}$ aromatic contribution is visible, and this for the three surfaces, indicating the complete transformation of toluene. In the same time, a strong band in the $1730-1755 \mathrm{~cm}^{-1}$ region evolved after 5 minutes of plasma treatment characteristic of the presence of a $\mathrm{C}=\mathrm{O}$ bond. As the plasma treatment time increased, the band increased, shifted to higher wavenumber after 10 minutes of plasma to reach 1775, 1770 and $1790 \mathrm{~cm}^{-1}$ on $\gamma-\mathrm{Al}_{2} \mathrm{O}_{3}, \mathrm{CeO}_{2}$ and $\mathrm{TiO}_{2}$, respectively (table 2 and figure 7). 
The non-symmetry of the bands and apparition of a shoulder $\left(1700-1725 \mathrm{~cm}^{-1}\right)$ at 10 minutes for $\mathrm{CeO}_{2}$ and $\mathrm{TiO}_{2}$ and 20 minutes for $\gamma-\mathrm{Al}_{2} \mathrm{O}_{3}$ indicate the presence of a carboxylic acid in addition to aldehyde or ester $[25,41]$. The bands at 1330,1250 and $1290 \mathrm{~cm}^{-1}$ on $\gamma-\mathrm{Al}_{2} \mathrm{O}_{3}, \mathrm{TiO}_{2}$ and $\mathrm{CeO}_{2}$, respectively, can be attributed to $\mathrm{C}-\mathrm{O}$ stretching. In addition, the broad shoulder of O-H stretching (2500-3500 cm-1) confirms the presence of carboxylic acid. Independently of the catalyst, the growing of the $1790-1770 \mathrm{~cm}^{-1}$ band is associated with the formation of a negative signal in the $\mathrm{OH}$ vibration domain $\left(3500-3700 \mathrm{~cm}^{-1}\right)$ showing that the species formed under plasma adsorb on $\mathrm{OH}$ surface groups. By increasing the plasma treatment duration, the main change is the shift of the $\mathrm{C}=\mathrm{O}$ band for more than 10 minutes of plasma. This shift could be assigned to the formation of bridged carbonates [42] on the catalysts surface showing the total oxidation of toluene under plasma treatment.

A band at $1345 \mathrm{~cm}^{-1}$ appeared after one minute and could also correspond to primary $\mathrm{O}-\mathrm{H}$ bending $(\delta-\mathrm{OH})$ or $=\mathrm{C}-\mathrm{OH}$ phenol stretching. The band increased and shifted to $1330 \mathrm{~cm}^{-1}$ until 20 minutes and remained constant until 60 minutes. At this wavenumber, the functional group identified is more likely $\mathrm{C}-\mathrm{O}$ from carboxylic acid or $=\mathrm{C}-\mathrm{OH}$ phenol stretching but also $\mathrm{N}-\mathrm{O}$ symmetrical stretching from olefinic compounds. However, other nitrogen related contribution were not identified.

On $\mathrm{CeO}_{2}$, less intense bands appear at 1414 and $1250-1216 \mathrm{~cm}^{-1}$ which could be due to the formation of carboxylic acids (O-H bending and C-O stretching, respectively) and at $1610 \mathrm{~cm}^{-1}$ which could be assigned to the formation of adsorbed formate species [43]. The relative intensity of this band decreases from $\gamma-\mathrm{Al}_{2} \mathrm{O}_{3}, \mathrm{TiO}_{2}$ to $\mathrm{CeO}_{2}$, following the increasing oxidative property (or basicity) of these oxides.

On the three surfaces, the band of $C=C$ stretching at $\sim 1460 \mathrm{~cm}^{-1}$ and at $\sim 1610 \mathrm{~cm}^{-1}$ broadened and increased until 60 minutes while the one at $\sim 1495 \mathrm{~cm}^{-1}$ decreased until complete disappearance. The increasing and broadening of the $1460 \mathrm{~cm}^{-1}$ band could be due to various stretching behavior such as $\mathrm{C}=\mathrm{C}$ of phenol or $\mathrm{C}=\mathrm{C}$ from alkenes indicating a rupture of the aromatic ring. A weak shoulder in the $2950-2930 \mathrm{~cm}^{-1}$ region, indicates the presence of $\mathrm{C}-\mathrm{H}$ stretching from methyl group only, without aromatic contribution. The presence of bands in the $2300-2400 \mathrm{~cm}^{-1}$ domain is associated to the presence of adsorbed $\mathrm{CO}_{2}$.

According to the results of various authors [44-52] and ours, we can propose some probable reaction mechanisms for toluene elimination. First of all, Kohno et al. [44] showed that, from the 3 pathways undertaken by NTAP species for VOC elimination, the electron impact would 
be the favored one as it presents the lowest reaction rate constant in the order of $10^{-6} \mathrm{~cm}^{3} . \mathrm{s}^{-}$

${ }^{1}$. The two other pathways, ion collisions and radical attack $\left(\mathrm{O}^{\bullet} / \mathrm{OH}^{\bullet}\right)$ would occur subsequently and contribute to toluene oxidation and ring opening reactions. The electronic impact would lead to the formation of benzene radical that would rapidly be oxidized in phenol. For the later, the aromatic cycle would be rapidly hydroxylated into hydroquinone, further oxidized in benzoquinone. Finally the ring would be opened by oxygen or $\mathrm{OH}$ radicals leading to the formation of aldehydes and carboxylic acids with different carbon chains length. Possible mechanisms are displayed in figure 8. As long as oxidative radicals are present, in addition to electronic impact, the reaction would continue until complete fragmentation into $\mathrm{CO}_{2}$ and $\mathrm{H}_{2} \mathrm{O}$ following various mechanisms that are currently not completely identified and still need further investigation. Additionally, methyl radical would be oxidized in formic acid followed by complete elimination in $\mathrm{CO}_{2} / \mathrm{H}_{2} \mathrm{O}$. It seems that the oxidation of the methyl group on toluene, leading to benzaldehyde and benzoic acid, is not the favored pathway undertaken for toluene oxidation by non-thermal plasma. In fact, from our results, it seems that the band related to $\mathrm{C}=\mathrm{O}$ apparition coincides with the complete disappearance of aromatic $\mathrm{C}-\mathrm{H}$ bands, indicating a rapid opening of the aromatic ring prior to the oxidation of the fragments into carboxylic acid.

\section{Conclusions}

This new infrared cell allows characterizing by DRIFT the adsorbed organic species on a catalyst surface under DBD non-thermal plasma and in controlled gaseous environment at atmospheric pressure, realizing then a true operando analysis of a catalyst surface submitted to the action of a non-thermal plasma. The method has proven to be so efficient that it was possible to follow the evolution of secondary compounds, arising from the oxidation of isopropanol and toluene. The plasma treatment of IPA molecules adsorbed on $\gamma-\mathrm{Al}_{2} \mathrm{O}_{3}, \mathrm{TiO}_{2}$ and $\mathrm{CeO}_{2}$ surfaces led to the formation of acetone, propene, acetic acid and/or formic acid. On $\mathrm{CeO}_{2}$ and $\mathrm{TiO}_{2}$ surface, only acids remained after 60 minutes of plasma treatment while $\gamma$ $\mathrm{Al}_{2} \mathrm{O}_{3}$ showed a small presence of acetone and propene on its surface. By contrast, the toluene oxidation by non-thermal plasma led to the rapid opening of the aromatic ring, followed by the total oxidation through carboxylic formation of the species arising from the toluene molecules fragmentation. These results should be considered as preliminary experiments 
probing the extended possibilities of this new IR cell to characterize in operando conditions a catalyst or any surface submitted to a non-thermal plasma and are able to improve the knowledge on plasma material interactions.

\section{Acknowledgments}

The authors would like to thank the French Ministry of Research for the funding of the PhD grant of A. Rodrigues.

\section{References}

1. Bogaerts A, Neyts E, Gijbels R, Van der Mullen J (2002) Spectrochim Acta B 57:609-658

2. Tendero C, Tixier C, Tristant P, Desmaison J, Leprince P (2006) Spectrochim Acta B 61:2-30

3. Kogelschatz U, Eliasson B and Egli W (1999) Pure Appl Chem 71:1819-1828

4. Van Durme J, Dewulf J, Leys C, Van Langenhove H (2008) Appl Cat B: Env 78:324-333

5. Hyun- Ha K, Plasma Process Polym (2004) 1:91-110

6. Vandenbroucke AM, Morent R, De Geyter N, Leys C (2011) J Hazard Mater 195:30-54

7. Tosi P, Ascenzi D, Franceschi P, Guella G (2009) Plasma Sources Sci T 18:034005

8. Tanarro I, Herrero VJ (2009) Plasma Sources Sci T 18:034007

9. Babayan SE, Ding G, Nowling GR, Yang X, Hicks RF (2002) Plasma Chem Plasma P 22:255269

10. Cruden BA, Rao MVVS, Sharma SP, Meyyappan M (2003) J Appl Phys 93:5053-5062

11. Rivallan M, Aiello S, Thibault-Starzyk F (2010) Rev Sci Instrum 81:103111

12. Nakagawa Y, Ono R, Oda T (2014) IEEE T Ind Appl 50:39-44

13. Liao X, Guo YF, He JH, Ou WJ, Ye DQ (2010) Plasma Chem Plasma P 30:841-853

14. Rivallan M, Fourré E, Aiello S, Tatibouët JM, Thibault-Starzyk F (2012) Plasma Process Polym 9:850-854

15. Kim HH, Teramoto Y, Negishi N, Ogata A (2015) Catal Today 256:13-22

16. Barakat C, Grajevat P, Guaitella O, Thévenet F, Rousseau A (2014) Appl Catal B: Env $147: 302-313$

17. Jarrige J, Vervisch $P$ (2006) J Appl Phys 99:113303

18. Karuppiah J, Sivachandiran L, Karvembu R, Subrahmanyam Ch (2010) Chem Eng J 165:194199 
19. Sivachandiran L, Thévenet F, Rousseau A (2013) Plasma Chem Plasma P 33:855-871

20. Al-Abduly A, Christensen P (2015) Plasma Sources Sci T 24:065006

21. Manley TC (1943) T Electrochem Soc 84:83-96

22. del Arco M, Gutiérez S, Martin C, Rives V (2001) Phys Chem Chem Phys 3:119-126

23. Ermini V, Finocchio E, Sechi S, Busca G, Rossini S (2000) Appl Cat A: Gen 167:157-167

24. Zaki MI, Hussein GAM, El-Ammawy HA, Mansour SAA, Polz J, Knözingze H (1990) J Mol Catal 57:367-378

25. Coates J (2000) Interpretation of infrared spectra, A practical approach, Encyclopedia of Analytical chemistry, Ed. R.A. Mayer, pp. 10815-10837

26. Al-Abadleh H.A., Grassian V.H. (2003) Langmuir 19:341-347

27. Devlin J.P., Buch V (1997) J. Phys Chem. B 101:1095-1098

28. Devlin J.P., Sadley J., Buch V. (2001) J. Phys. Chem. A 105:974-983

29. Narengerile, Watanabe T, Chem Eng Sci (2012) 69:296-303

30. Neaţu S, Sacaliuc-Pârvulescu E, Lévy F, Pârvulescu VI (2009) Catal Today 142:165-169

31. Hasan MA, Zaki MI, Pasupulety L (2003) Appl Cat A: Gen 243:81-92

32. Benaliouche F, Boucheffa Y, Thybault-Starzyk F (2012) Micropor Mesopor Mat 147:10-16

33. P. Lakshmanan, L. Delannoy, C. Louis, N. Bion, J. M. Tatibouët (2013) Cat Sci Tec 3:2918-2925

34. Parkyns N D (1969) J Chem Soc A 410-417

35. Thornton E W, Harrison P G (1975) J Chem Soc, Faraday Trans 1: 461-472

36. Morterra C, Ghiotti G, Garrone E, Boccuzzi F (1976) J Chem Soc, Faraday Trans 72 : 2722 2734

37. Lee D H, Condrate Sr. R A (1995) Mater Lett 23: 241-246

38. Digne $M$, Sautet $P$, Raybaud $P$, Euzen $P$, Toulhoat $H$ (2002) J Catal 211 : 1-5

39. Harrison P G, Guest A (1987) J Chem Soc, Faraday Trans 83 : 3383-3397

40. Wachs I E (1995) Colloid Surface A 105: 143-149

41. Larkin PJ (2011) IR and Raman Spectroscopy: Principles and Spectral Interpretation, Elsevier

42. Little LH (1966) Infrared Spectra of Adsorbed Species, Academic Press, New York 43. Köck EM, Kogler M, Bielz T, Klötzer B, Penner S (2013) J Phys Chem C 117:17666-17673

44. Kohno H, Berezin AA, Chang JS, Tamura M, Yamamoto T, Shibuya A, Hondo S (1998) IEEE T Ind Appl 34:953-966 
45. Zhu T, Wan YD, Li Y, He XW, Xu DY, Shu XQ, Liang WJ, Jin YQ (2011) Int J Environ Sci Tec 8:621-630

46. Huang H, Ye D, Leung DYC, Feng F, Guan X (2011) J Mol Catal A: Chem 336:87-93

47. Xiao G, Xu W, Wu R, Ni M, Du C, Gao X, Luo Z, Cen K (2014) Plasma Chem Plasma P 34:10331065

48. Klotz B, Barnes I, Becker K H, Golding B T (1997) J Chem Soc, Faraday Trans. 93: 1507-1516

49. An G, Sun Y, Zhu T, Yan X (2011) Chemosphere 84:1296-1300

50. Cheng H H, Chen S S, Yoshizuka K, and Chen Y C, J Water Chem Tech (2012) 34: 179-189

51. Lukes P, Locke B R (2005) J Phys D: Appl. Phys. 38: 4074-4081

52. Berndt T, Böge O (2001) Phys Chem Chem Phys (2001) 3: 4946-4956 
Table 1: Catalysts characteristics

\begin{tabular}{|c|c|c|}
\hline Oxide & Supplier & Surface area $\left(\mathrm{m}^{2} \cdot \mathrm{g}^{-1}\right)$ \\
\hline$\gamma-\mathrm{Al}_{2} \mathrm{O}_{3}$ & Degussa & 102 \\
\hline $\mathrm{TiO}_{2} \mathrm{P} 25$ & Sigma Aldrich & 9 \\
\hline $\mathrm{CeO}_{2}$ & Prolabo & 23 \\
\hline
\end{tabular}

Table 2: Shift of the $\mathrm{C}=\mathrm{O}$ band as a function of plasma treatment time and corresponding chemical groups [25, 34].

Ald: aldehyde; carb: carbonate

\begin{tabular}{|c|c|c|c|c|c|c|c|c|}
\hline $\begin{array}{l}\text { Plasma time } \\
\text { (min) }\end{array}$ & 0 & 1 & 5 & 10 & 20 & 30 & 45 & 60 \\
\hline \multicolumn{9}{|c|}{ Wavenumber maxima $\left(\mathrm{cm}^{-1}\right)$} \\
\hline $\mathrm{Al}_{2} \mathrm{O}_{3}$ & - & 1740 & 1740 & 1745 & 1769 & 1775 & 1775 & 1775 \\
\hline $\begin{array}{l}\text { Corresponding } \\
\text { carbonyl } \\
\text { group }\end{array}$ & & $\begin{array}{l}\text { Aldehyde/ } \\
\text { ester }\end{array}$ & Ald/ester & Ald/ester & $\begin{array}{l}\text { Ald/ester/ } \\
\text { acid }\end{array}$ & Carb. & & $\longrightarrow$ \\
\hline $\mathrm{CeO}_{2}$ & - & 1736 & 1736 & 1760 & 1783 & 1770 & 1770 & 1770 \\
\hline $\begin{array}{l}\text { Corresponding } \\
\text { carbonyl } \\
\text { group }\end{array}$ & & $\begin{array}{l}\text { Aldehyde/ } \\
\text { ester }\end{array}$ & $\begin{array}{l}\text { Ald/ } \\
\text { ester }\end{array}$ & $\begin{array}{l}\text { Ald/ester/ } \\
\text { acid }\end{array}$ & Carb. & & & \\
\hline $\mathrm{TiO}_{2}$ & - & 1750 & 1750 & 1775 & 1782 & 1790 & 1790 & 1790 \\
\hline $\begin{array}{l}\text { Corresponding } \\
\text { carbonyl } \\
\text { group }\end{array}$ & - & $\begin{array}{l}\text { Aldehyde/ } \\
\text { ester }\end{array}$ & $\begin{array}{l}\text { Ald/ } \\
\text { ester }\end{array}$ & $\begin{array}{l}\text { Ald/ester/ } \\
\text { acid }\end{array}$ & Carb. & & & $\longrightarrow$ \\
\hline
\end{tabular}




\section{Figures captions}

Scheme 1: Adsorption mode of IPA ( $M$ = metallic cation)

Figure $1(A)$ : Schematic of the IR/plasma cell.

Figure $1(B)$ : Views of the disassembled cell (a to d).

Figure 2: Lissajous curve at $\mathrm{U}_{\mathrm{a}}=16 \mathrm{kV}$ and $\mathrm{f}=500 \mathrm{~Hz}$

Figure 3: Injected power in the DBD reactor as a function of the input voltage at atmospheric pressure, under a constant dry air flow of $30 \mathrm{~mL} \cdot \mathrm{min}^{-1}$.

Figure 4: DRIFT Spectra on $\gamma-\mathrm{Al}_{2} \mathrm{O}_{3}$

(A) In situ IR spectra of the evolution of adsorbed isopropanol as a function of plasma treatment time from bottom to top (adsorbed IPA then 1, 5, 10, 20, 30, 45 and 60 min of plasma treatment)

(B) Spectra of adsorbed IPA after 60 min of plasma treatment and adsorbed acetone, acetic acid and formic acid (from bottom to top)

Figure 5: DRIFT Spectra on $\mathrm{TiO}_{2}$

(A) In situ IR spectra of the evolution of adsorbed isopropanol as a function of plasma treatment time from bottom to top (adsorbed IPA then 1, 5, 10, 20, 30, 45 and 60 min of plasma treatment)

(B) Spectra of adsorbed IPA after 60 min of plasma treatment and adsorbed acetone, acetic acid and formic acid (from bottom to top)

Figure 6: DRIFT Spectra on $\mathrm{CeO}_{2}$

(A) In situ IR spectra of the evolution of adsorbed isopropanol as a function of plasma treatment time from bottom to top (adsorbed IPA then 1, 5, 10, 20, 30, 45 and 60 min of plasma treatment)

(B) Spectra of adsorbed IPA after 60 min of plasma treatment and adsorbed acetone, acetic acid and formic acid (from bottom to top) 
Figure 7: In situ DRIFT spectra of the evolution of toluene on A) $\left.\gamma-\mathrm{Al}_{2} \mathrm{O}_{3}, \mathrm{~B}\right) \mathrm{CeO}_{2}$ and C) $\mathrm{TiO}_{2}$ as a function of plasma treatment time from bottom to top (adsorbed toluene then 1, 5, 10, 20, 30,45 and 60 min of plasma treatment).

Figure 8: Possible mechanism pathways and intermediates of toluene oxidation and degradation 
Scheme 1: Adsorption mode of IPA ( $M=$ metallic cation)<smiles>[M]OCP(OC)C(C)C</smiles>

(a)

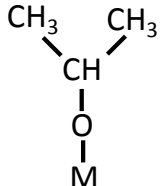

(b)

Figure 1(A): Schematic of the IR/plasma cell.

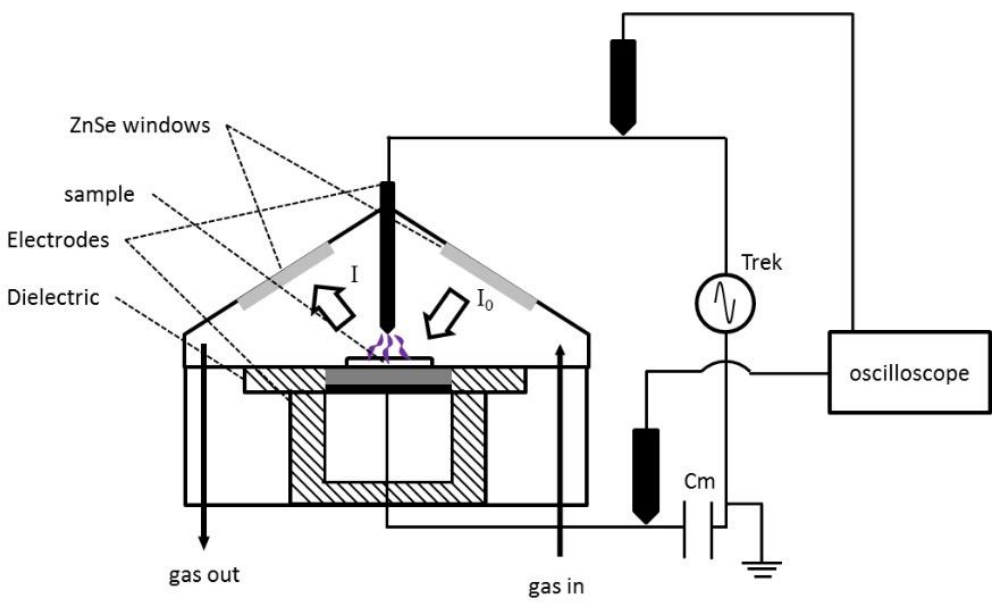

Figure 1 (B): Views of the disassembled cell (a to d).
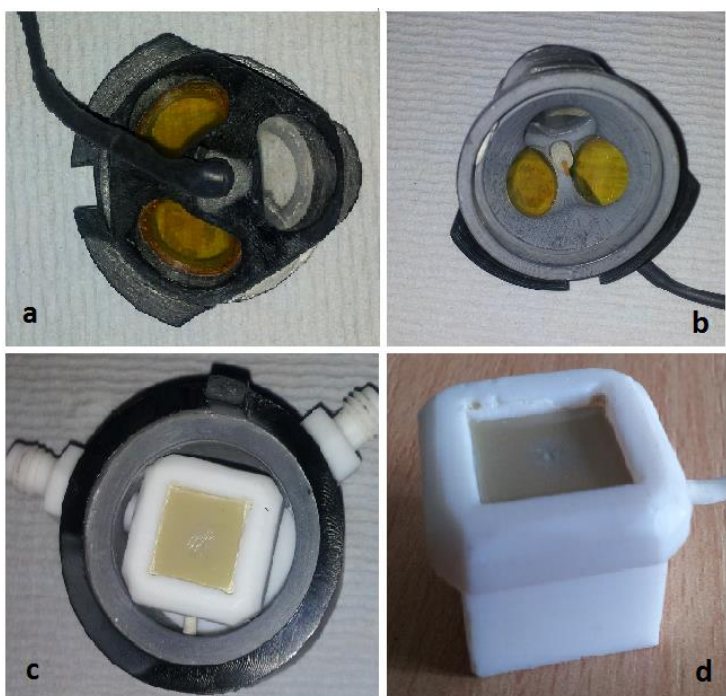
Figure 2: Lissajous Curve at $\mathrm{U}_{\mathrm{a}}=16 \mathrm{kV}$ and $\mathrm{f}=500 \mathrm{~Hz}$

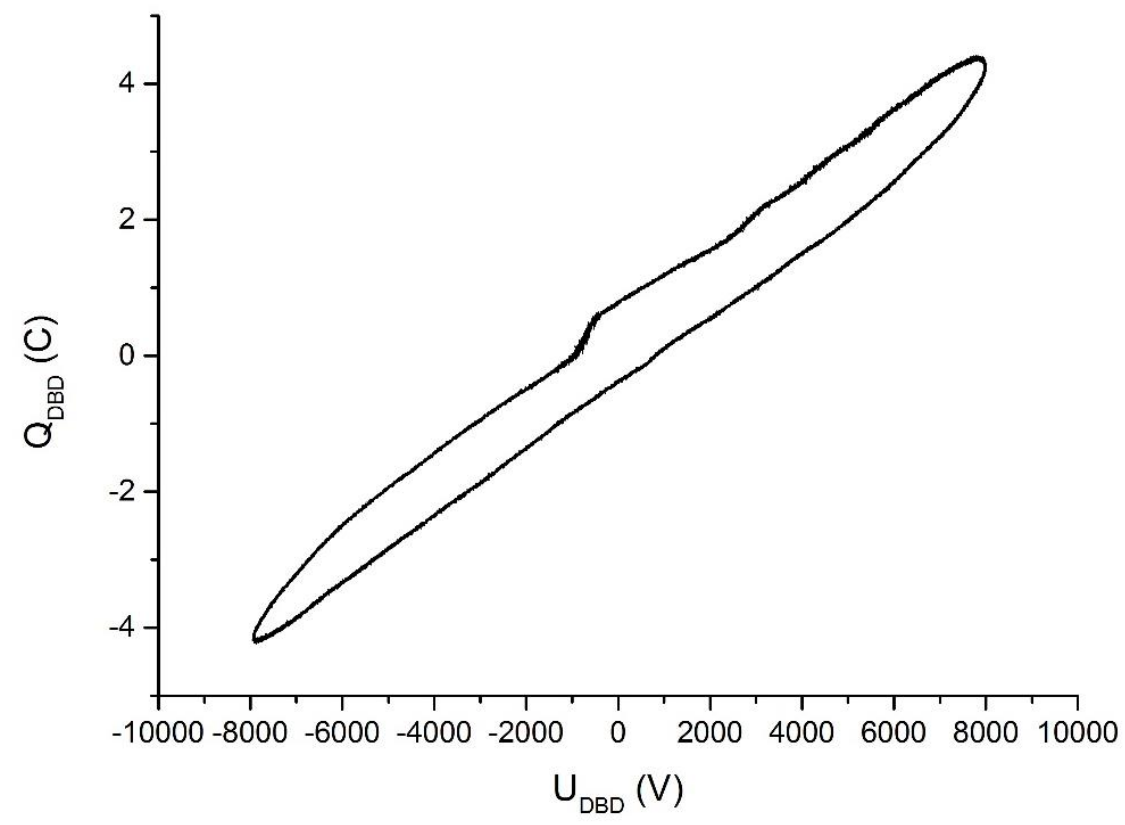

Figure 3: Injected power in the DBD reactor as a function of the input voltage at atmospheric pressure, under a constant dry air flow of $30 \mathrm{~mL} \cdot \mathrm{min}^{-1}$.

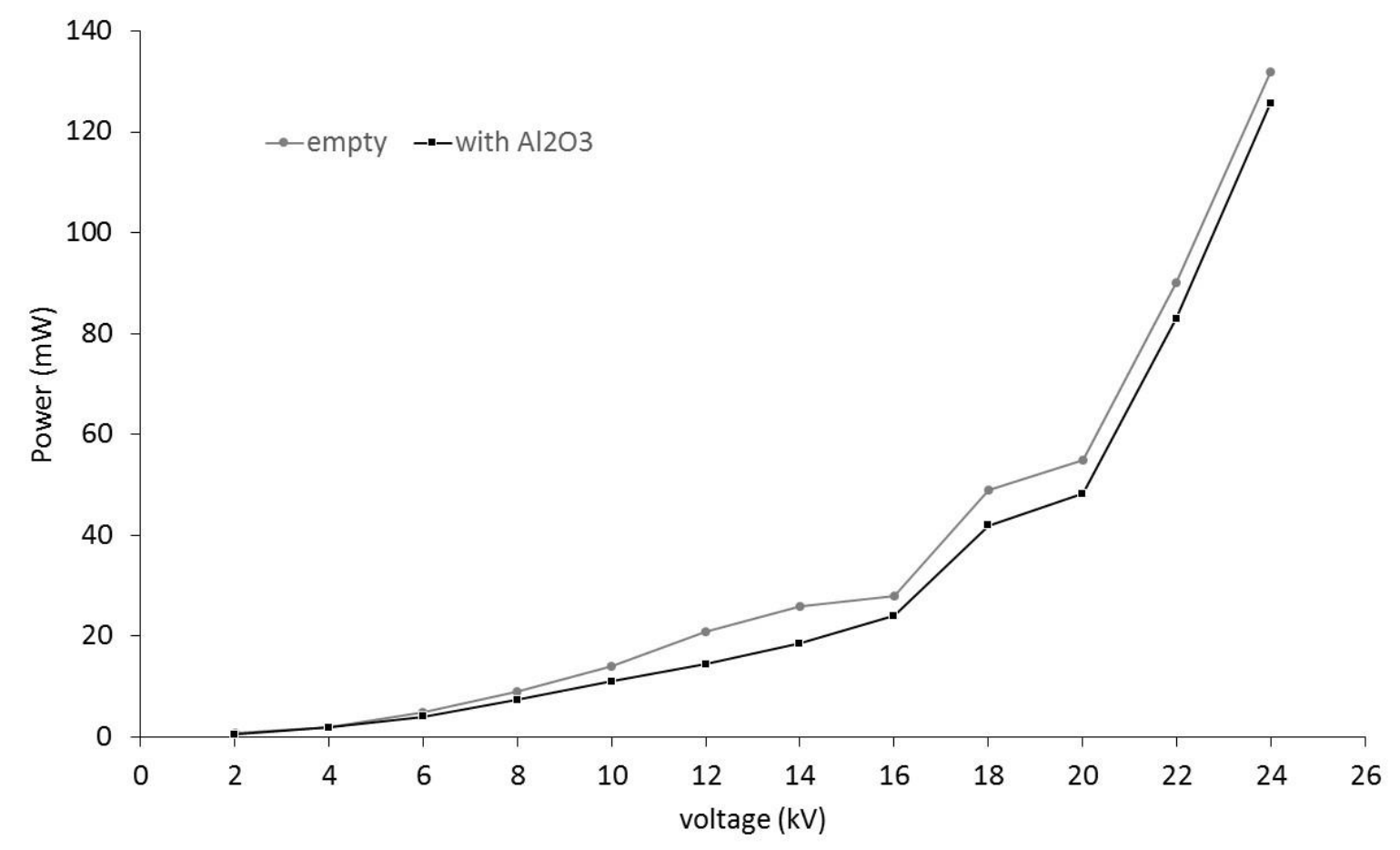


Figure 4: DRIFT Spectra on $\gamma-\mathrm{Al}_{2} \mathrm{O}_{3}$

(A) In situ IR spectra of the evolution of adsorbed isopropanol as a function of plasma treatment time from bottom to top (adsorbed IPA then 1, 5, 10, 20, 30, 45 and 60 mins of plasma treatment)

(B) Spectra of adsorbed IPA after 60 mins of plasma treatment and adsorbed acetone, acetic acid and formic acid
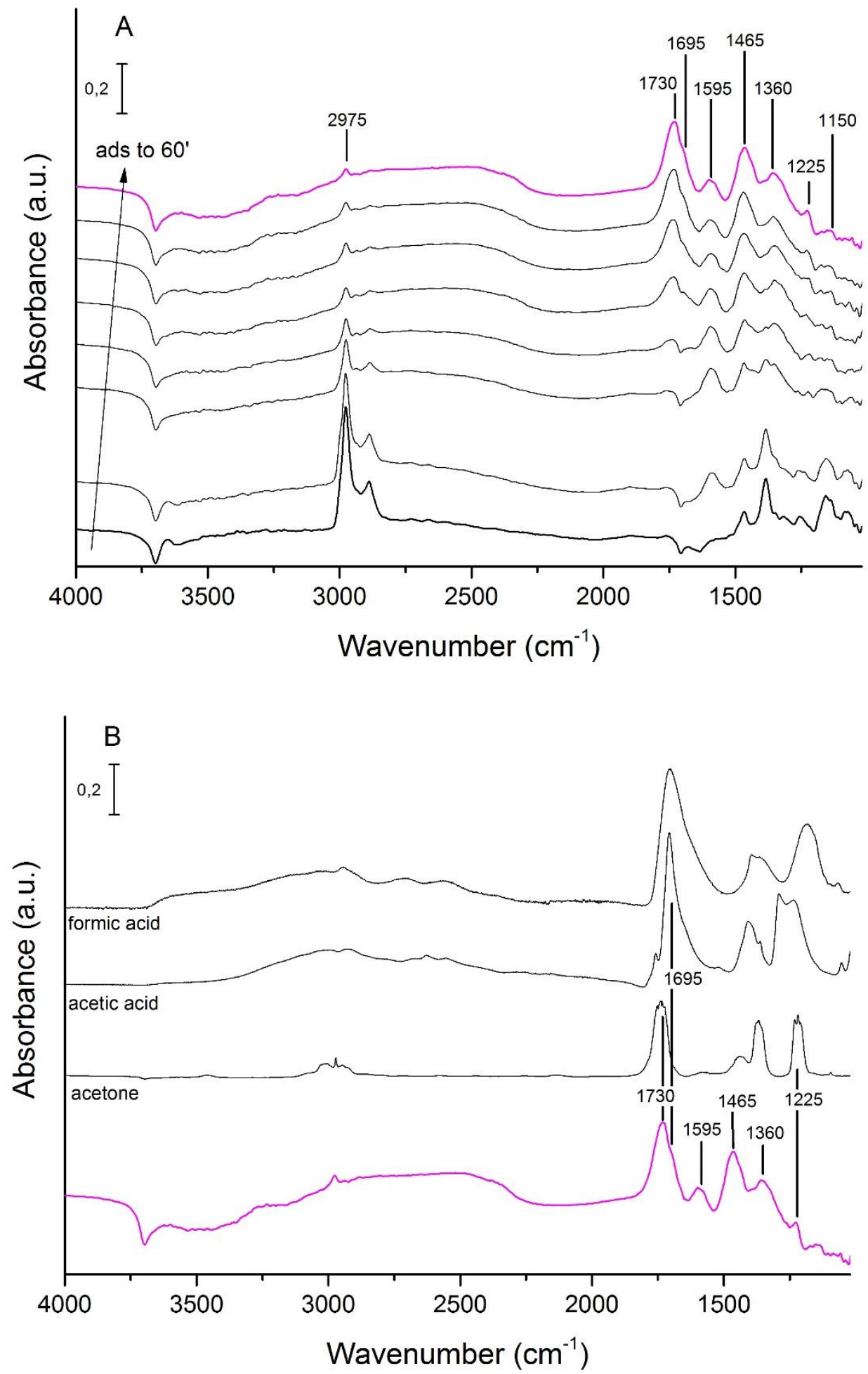
Figure 5: DRIFT Spectra on $\mathrm{TiO}_{2}$

(A) In situ IR spectra of the evolution of adsorbed isopropanol as a function of plasma treatment time from bottom to top (adsorbed IPA then 1, 5, 10, 20, 30, 45 and 60 mins of plasma treatment)

(B) Spectra of adsorbed IPA after 60 mins of plasma treatment and adsorbed acetone, acetic acid and formic acid
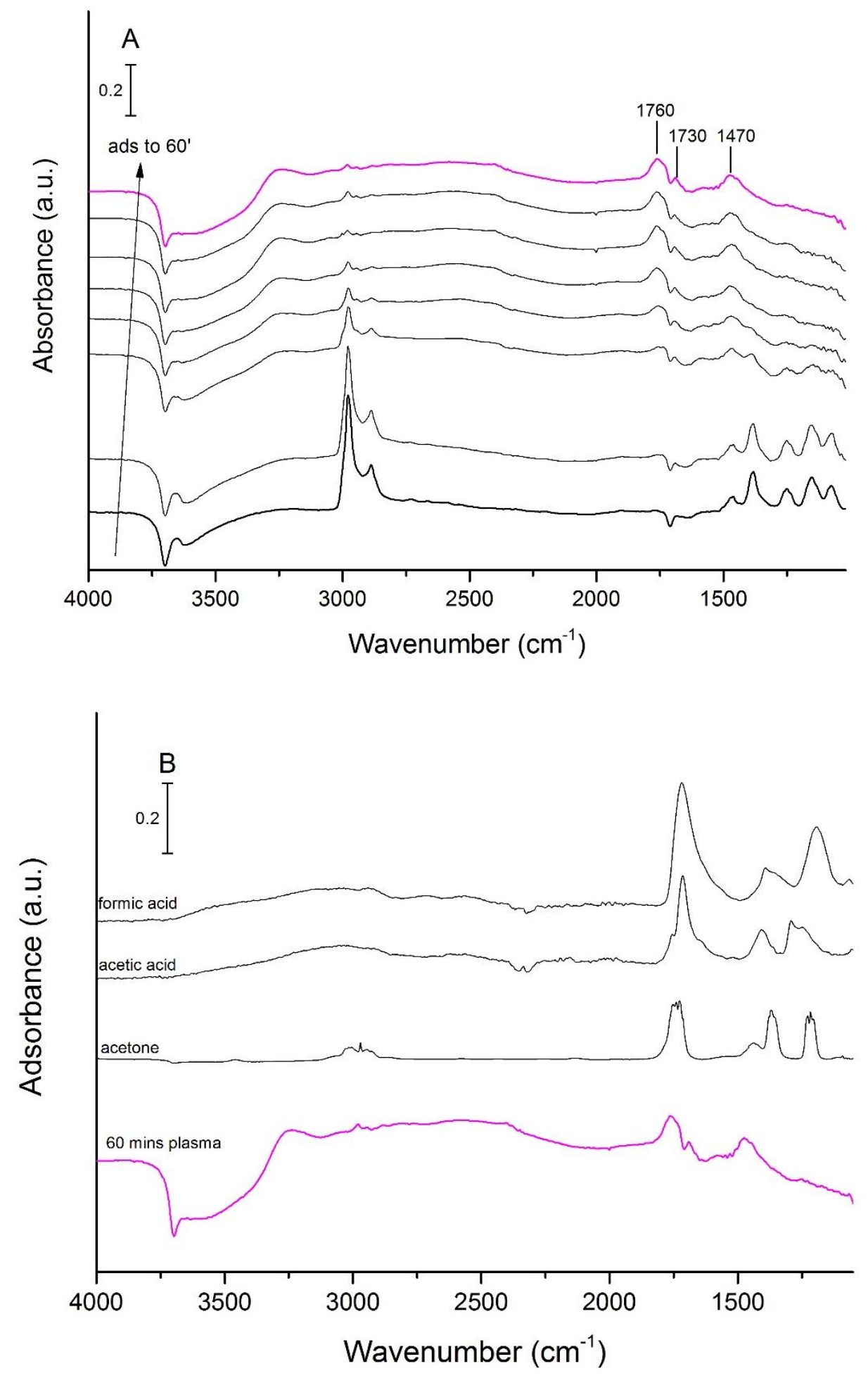
Figure 6: DRIFT Spectra on $\mathrm{CeO}_{2}$

(A) In situ IR spectra of the evolution of adsorbed isopropanol as a function of plasma treatment time from bottom to top (adsorbed IPA then 1, 5, 10, 20, 30, 45 and 60 mins of plasma treatment)

(B) Spectra of adsorbed IPA after 60 mins of plasma treatment and adsorbed acetone, acetic acid and formic acid
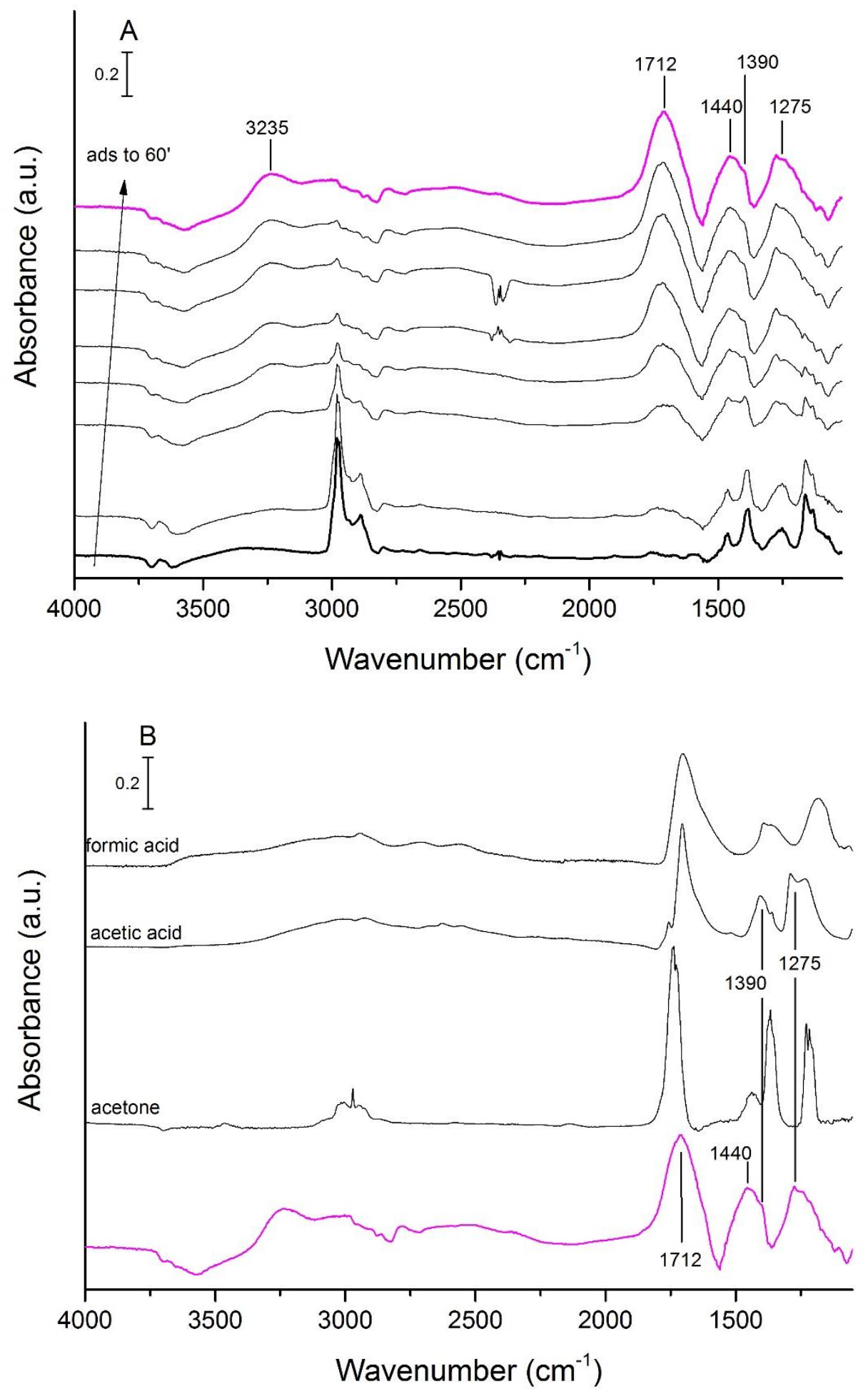
Figure 7: In situ DRIFT spectra of the evolution of toluene on A) $\left.\gamma-\mathrm{Al}_{2} \mathrm{O}_{3}, \mathrm{~B}\right) \mathrm{CeO}_{2}$ and C) $\mathrm{TiO}_{2}$ as a function of plasma treatment time from bottom to top (adsorbed toluene then 1, 5, 10, 20, 30,45 and 60 min of plasma treatment). 

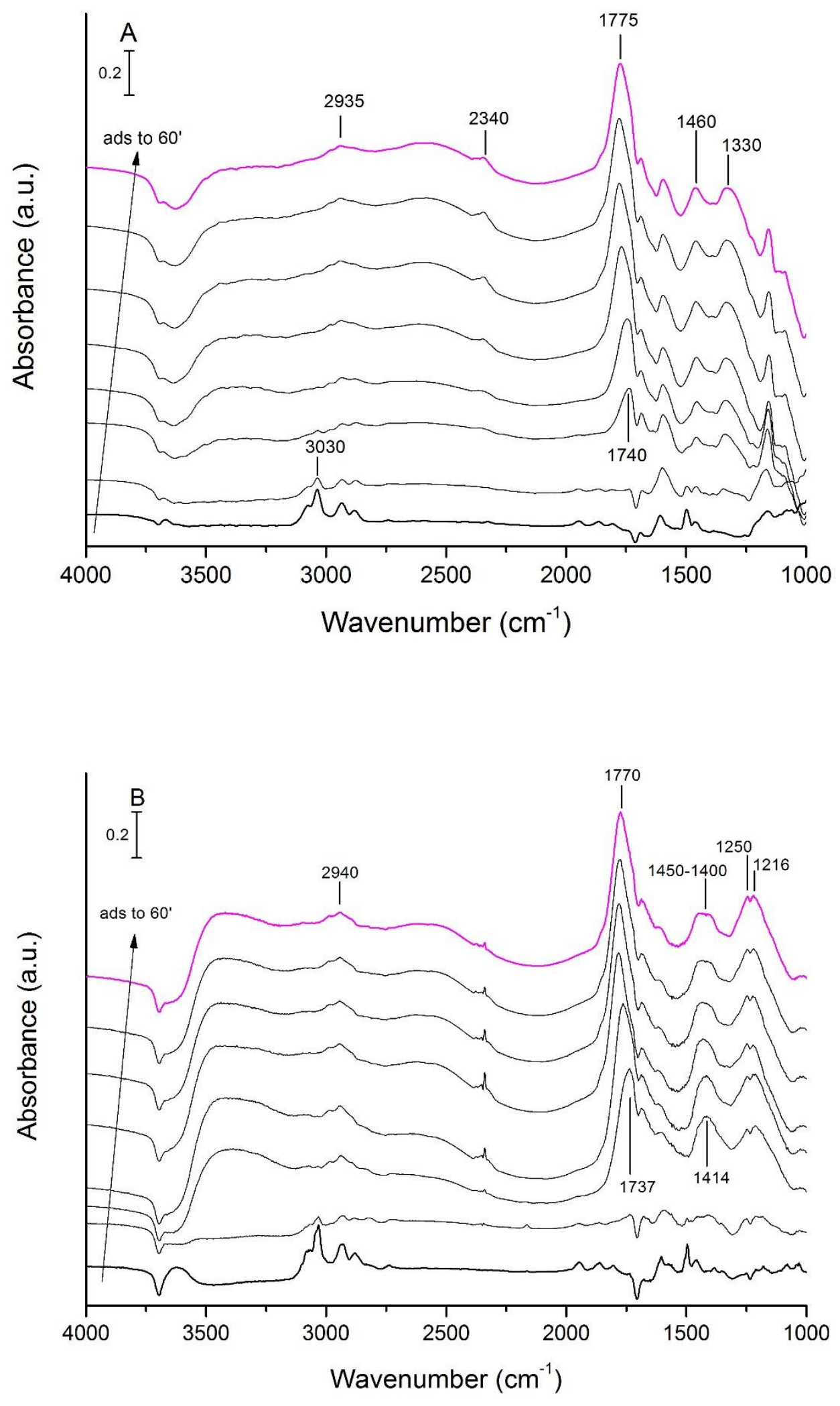


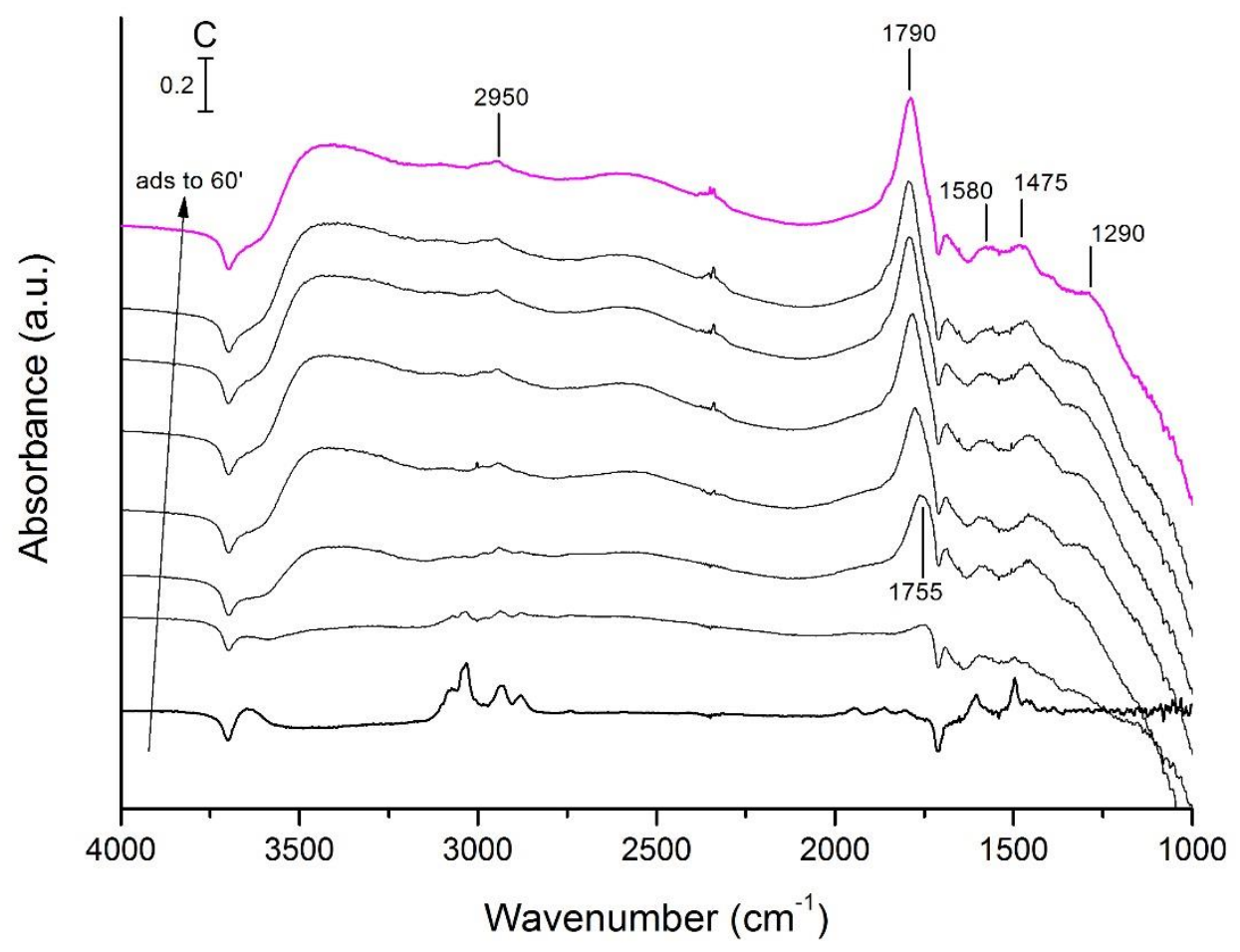


Figure 8: Possible mechanism pathways and intermediates of toluene oxidation and degradation

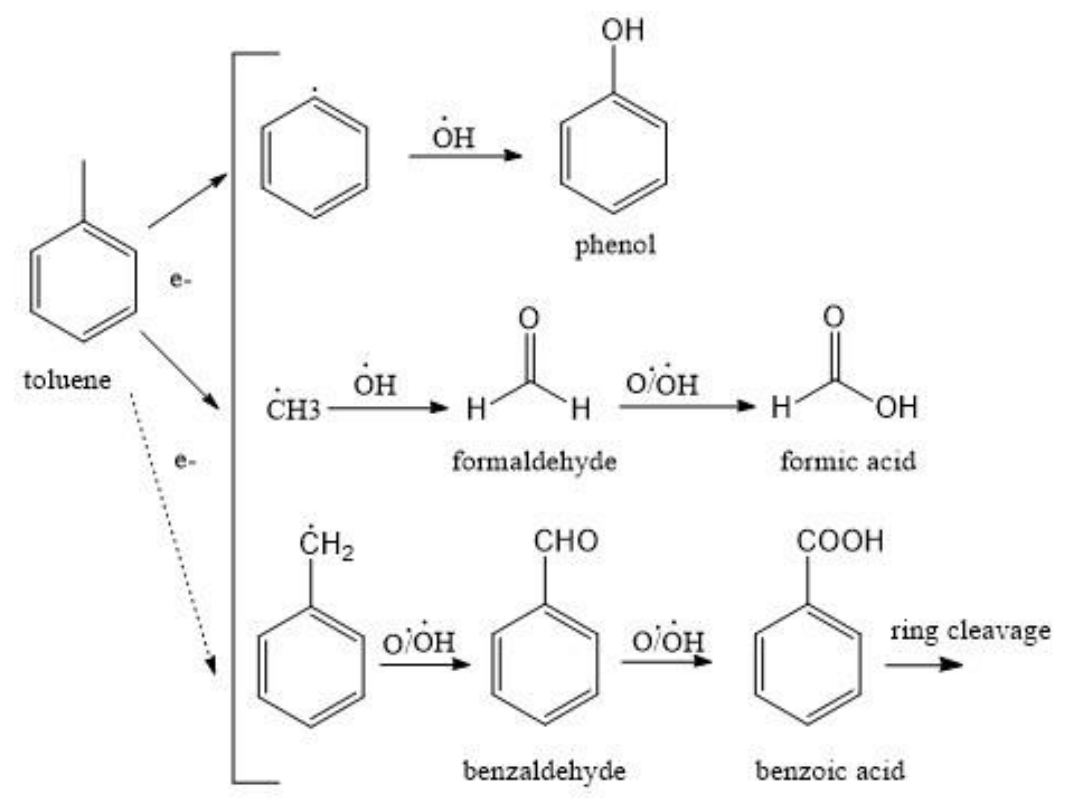

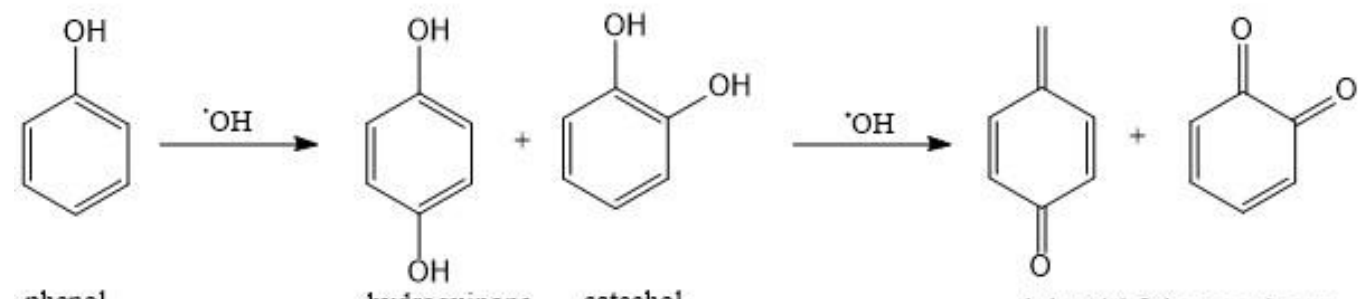

phenol hydroquinone catechol 1,4 and 1,2-benzoquinone<smiles>CCCCCCCCCCCCCCCCCCCC(=O)OC(C)=O</smiles>

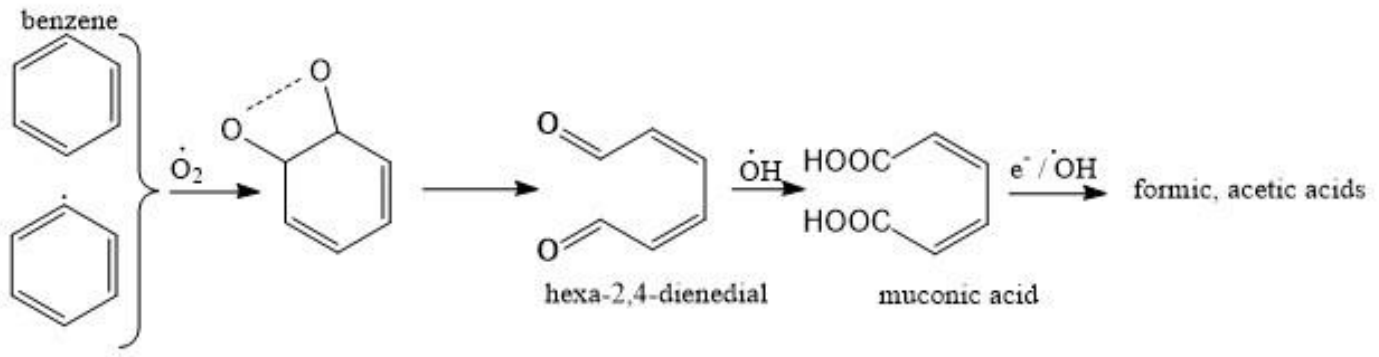
benzene radical 